\title{
OPTIMALISASI METODE GERAK SERTA LAGU UNTUK MENINGKATKAN KECERDASAN PESERTA DIDIK
}

\author{
Rifatin \\ Universitas Nurul Jadid, Paiton Probolinggo Jawa Timur \\ atinrifa84@gmail.com
}

\begin{abstract}
This research is based on the lack of variations in songs used by teachers in learning for early childhood. The purpose of this study is to develop motion and song activities that can be used as a choice of activities that can be done to improve children's intelligence and to find out whether motion activities and songs developed by researchers are effective to improve children's intelligence. This type of research is descriptive qualitative research, in order to obtain data in this study the authors use classroom action research methods through observation methods, capacity assessment formats and documentation. From the data analysis it is known that the intelligence of children after being given an experiment through motion activity and better than the intelligence of children before being given experiments through motion and song activity. In general, motion and song can develop children's kinesthetic intelligence, through body movements such as by bending with rotating the body, it can be concluded that movement and song activity is effective to improve children's intelligence.
\end{abstract}

Keywords: optimization, methods, motion and song, intelligence.

\section{PENDAHULUAN}

Anak usia dini memiliki potensi yang besar dalam mengembangkan aspekaspek perkembangannya. Anak mulai sensitif menerima segala rangsangan dari luar. Salah satu aspek perkembangan yang memiliki potensi yang sangat besar yakni perkembangan kecerdasannya.anak usia dini merupakan anak mulai lahir hingga usia 6 tahun.anak usia dini merupakan anak yang berbeda, unik serta mempunyai karakter tersendiri menurut tahapan usianya. ${ }^{1}$

Anak usia dini lebih sering melakuakan aktivitas yang melibatkan motorik kasarnya seperti berlari, melompat, menendang. Oleh sebab itu kegiatan pembelajaran seharusnya disusun sesuai kebutuhan juga perkembangan anak. . Sebagian besar kegiatan yang disusun oleh guru yakni untuk pengembangan kognitif,

${ }^{1}$ Dadan Suryana, 'Hakikat Anak Usia Dini', Dasar-DasarPendidikan TK, 2014, 65. 
bahasa, sains dan motorik halus. Hal ini dikarenakan adanya tuntutan khususnya dari orang tua bahwa setelah lulus dari taman kanak-kanak, anak harus sudah pandai membaca dan menulis.

Kemungkinan besar perkembangan fungsi otak berjalan berjalan beriringan dengan keterampilan motorik pada usia dini. Oleh sebab itu, motorik menjadi perembangan yang sangat pentinguntuk dilatih dan dikembangkan terhadap anakanak usia dini. ${ }^{2}$

Gerak adalah bagian terpenting bagi perkembangan motorik anak. Banyak guna yang didapatkan anak ketika ia mulai terampil dalammenguasai gerakan yakni badan semakain sehat, lebih mandiri, percaya diri, serta social emosialnya juga akan tumbuh dengan baik. Melalui gerak anak mampu mengekspresikan dirinya.

Untuk mengembangkan serta meningkatkan kecerdasan anak diperlukan adanya kondisi dan stimulasi.Pendidik harus menyusun sebuah kegiatan pembelajaran yang membuat anak senang dan sesuai dengan keinginan anak, diantaranya yang dapat digunakan yakni melalui lagu atau nyanyian.

Gerak serta lagu mempunyai banyak manfaat tidak hanya untuk menyenangkan hati anak melainkan dapat difungsikan sebagai sarana penyampaian informasi yang menyenangkan untuk anak.Lagu bisa dirancang sedemikian rupa hingga tercapai sebuah tujuan pembelajaran atau tujuan materi yang ingin disampaikan.Selanjutnya "gerak serta lagu adalah termasuk kegiatan yang bisa untuk digunakan pada sebuah pembelajaran motorik, sebab gerak serta lagu adalah sebuah kegiatan yang mengharuskan anak untuk bergerak, seperti halnya kegiatan senam maupun olahraga. ${ }^{3}$

Seiring kemajuan zaman nyanyian ataupun lagu untu anak sudah sangat jarang sekali ditemukan. Bahkan sering dijumpai anak usia dini menyanyikan lagulagudewasa yangtidak sesuai untuk usia mereka, atau sering sekali lagu yang di terapkan pada pembelajaran sehari-harimerupakan lagu dewasa yang hanya diganti kata-kata atau liriknya saja sehingga hal tersebut menyulitkan anak. Kurangnya

${ }^{2}$ Dudi Gunawan \& Marisyanti Indahsari, 'Pengembangan Keterampilan Gerak Dasar Motorik Kasar Melalui Pembelajaran Seni', Jurnal Penelitian Pendidikan, 16.1 (2016), 32-39.

${ }^{3}$ Ni Kadek Nelly Paspiani, 'Kegiatan Latihan Gerak Dan Lagu (Jeruk Bali) Untuk Meningkatkan Perkembangan Motorik Kasar Pada Anak Usia Dini', Pendidikan Anak, IV.1 (2015), 538-543. 
mengerti orang tuaserta pendidik mengenai perkembangan lagu untuk anak yang menyebabkan anak-anak usia dini lebih sering menyanyikan lagu-lagu yang tidak sesuai untuk usia mereka.

Lagu atau nyanyian bisa berfungsi untuk meningkatkan kecerdasan. Anak usia dini belajar dengan pengalaman langsung, contohnya melalui lagu. Dengan metode gerak serta lagu yang dinyanyikan secara langsung akan memberikan sebuah pengetahuan baru untuk anak. Hal ini tidaklah mengherankan, karena lagu pada dasarnya adalah bentuk dari bahasa nada, yaitu bentuk dan tinggi rendahnya suara.Sedangkan, bahasa nada justru akan membawa mereka pada suasana riang, syahdu, sedih dan semangat. ${ }^{4}$ Metode gerak serta lagu akan memberikan pengalaman secara langsung kepada anak mengenai gerak sehingga dapat menambah pengalaman gera anak. Melalui pengalaman gerak itulahyang nantinya bisa menambah kecerdasan anak.Jika gerak sempurna yang bersumber dari gabungan antara pikiran dan fisik tersebut terlatih dengan baik, apapun yang dikerjakan orang tersebut akan berhasil dengan baik, bahkan sempurna. ${ }^{5}$ Metode gerak serta lagu cocok digunakan sebagai pilihan kegiatan untuk anak, hal itu karena lagu melekat dengan anak sehingga apabila dilakukan pengulangan anak tidak mudah merasa bosan

Gerak serta lagu dapat meningkatkan semangat anak untuk senam ataupun berolahraga.Sebab dengan gerak serta lagu mereka bisa bergerak sekaligus mendengarkan music ataupun lagu. Kegitan gerak serta lagu banyak kegunaannya, beberapa manfaat gerak serta lagu itu dapat meningatkan motorik kasar, meningkatkan kreatifitas, belajar bersosialisasi dan bekerja sama, melatih kedisiplinan, dan melatih konsentrasi anak. Bukankah sebagai pendidik harus memberikan yang terbaik untuk anak didik kita?

\section{OPTIMALISASI PROGRAM PENDIDIKAN}

Optimalisasi berasal dari kata dasar optimal yang mempunyai arti terbaik, tertinggi, paling menuntungkan, menjadikan paling baik, menjadikan paling tinggi, pengoptimalan proses, cara, perbuatan mengoptimalkan. sehingga optimalisasi

\footnotetext{
${ }^{4}$ Retno Tri Wulandari, 'Pembelajaran Olah Gerak Dan Tari Sebagai Sarana Ekspresi Dan Apresiasi Seni Bagi Anak Usia Dini’.jurnal pendidikan 2017. H. 34-35

${ }^{5}$ Yenti Yunita, 'Meningkatkan Kecerdasan Kinestetik Anak Melalui Teknik Bernyanyi Lagu-Lagu Di Tk Aisyiyah 1 Curup', 2014. H. 23-24
} 
adalah proses untuk membuat sesuatu yang lebih baik. Pendidikan adalah cara untuk meningkatkan kemampuan supaya hidup anak maju dan sempurna. ${ }^{6}$ Optimalisasi program dalam sebuah pendidikan dimaksudkan untuk mencapai standard program yang lebih bagus dalam sebuah pendidikan .

Pembelajaran seni pada Taman Kanak-kanak bisa dijadikan media yang baikdalam pengembangkan pengetahuan, keterampilan, kreativitas serta sensitivitas anak. ${ }^{7}$

Keberhasilan sebuah pendidikan tidak terlepas oleh kualitas pendidik. Sekolah unggulan selalu berupaya dan terus menerus untuk selalu meningkatkan mutu pendidikan upaya penigkatan mutu pendidikan memerlukan cara peningkatan mutu pembelajaran karena muara dari berbegai rancangan pendidikan adalah pada berjalannya rancangan pembelajaran yang berkualitas. Usaha untuk mengoptimalkan sebuah program akan tercapai dengan adanya peningkatan kualitas pendidikan.

\section{GERAK DAN LAGU ANAK USIA DINI}

Kegiatan gerak serta lagu sangat berkaitan erat serta tidak bisa dipisahkan terutama didalam memberikan pembelajaran terhadap anak-anak.Pembelajaran gerak serta lagu adalah kegiatandalam bermain sambil belajar serta belajar sambil bermain, kegiatanyang dikerjakan melalui gerak serta lagu diharapkan dapat menyenangkan anak serta menyentuh perkembangan bahasa, kepekaan terhadap irama musik, perkembangan motorik, rasa percaya diri, juga keberanian mengambil resiko.

Materi program dalam kurikulumbisamengembangkan terhadapkecerdasan fisik diantarany: aktivitas fisik dan modeling. ${ }^{8}$ Pengembangan fisik motorik bisa dijadikan sebagai pengembangan kesempatan agar menjadi pendidikan yang berkualitas berlaku untuk semua, mulai dari anak usia dini sampai perguruan tinggi.

Saat ini saat dimana anak biasanya dapat mengembangkan potensinya .Dari itu, anak pada usia dini diarahkan agar mempunyai keterampilan tersebut. Karena erat

${ }^{6}$ Hasan Baharun, Pengembangan Kurikulum: Teori Dan Praktik (Konsep, Prinsip, Model, Pendekatan Dan Langkah-Langkah Pengembangan Kurikulum PAI) (Yogyakarta: Cantrik Pustaka, 2017).

7 N Widianawati Inovete.(2), 'Pengaruh Pembelajaran Gerak Dan Lagu Dalam Meningkatkan Kecerdasan Musikal Dan Kecerdasan Kinestetika Anak Usia Dini', Academia.Edu, 2.Edisi Khusus (2011), 222-225 <http://www.academia.edu/download/34063262/22NANA_WIDHIANAWATI-bl.pdf>.

${ }^{8}$ Sri Kadarwati, 'Mengembangkan Kecerdasan Anak Usia Dini Melalui Pembelajaran Berbasis Pendidikan Kreatif', 2.1, 43-66. 


\section{Rifatin}

kaitannya antara kecerdasan kinestetik dengan motorik kasar anak. Supaya anak dapat menggerakkan tubuhnya menggunakan otot-otot atau bagian dari sebagian badan yang diperoleh dari keaktifan anak itu sendiri.sebagian pembelajaran terpenting dalam kehidupan diperoleh pada saat kanak-kanakyang paling awal dan pembelajaran itu sebagian besar diperoleh dari bermain. ${ }^{9}$

Metode gerak serta lagu merupakan pembelajaran dimana anak ajari materi pembelajaran menggunakan gerak dan lagu. Gerak dan lagu juga di pakai dapat beruapa lagu dengan tariannya. Gerak dan lagu diberikan untukmempermudah anak dalam menerima pembelajaran dan mengembangkangkan kecerdasannya.tari adalah gerak-gerak yang diberi bentuk dan ritmis pada badan didalam ruang.Metode gerak dan lagu mengembangkan 6 aspek perkembangan kemampuan anak yaitu nilai moral serta agama, fisik, social, emosional emosional, bahasa, kognitif dan seni.

Pembelajaran gerak serta lagu yang kreatif merupakan kegiatan bernyanyi sambil bergerak diiringi irama musik dan lagu dengan melakukan inovasi pembelajaran untuk meningkatkan motorik kasar, meningkatkan kreativitas, belajar bersosialisasi dan bekerjasama, melatih kedisiplinan, dan melatih kosentrasi anak. ${ }^{10}$ Kecerdasan anak juga dapat dilihat bakatnya secara fisik bagaimana ia bisa terampil memainkan tangannya. Kecerdasan yang setara dengan kecerdasan lainnya.Akan tetapi, sebelum anak dapat mengekspresikan gerakannya, hendaknya sudah dapat mengetahui variasi gerakan-gerakan tubuhnya.

Lagu juga salah satu bentuk dari musik.Lagu dan musik saling berkaitan. Akan menjadi sebuah hasil seni yang bagus jika lagu dan musik gabungkan satu sama lain.

Gerakan-gerakan yang digunakan merupakan gerakan anak sehari-hari seperti melompat, meloncat, berjalan, bertepuk tangan, melambaikan tangangerakan-gerakan yang diberikan harus melihat keadaan anak didik.Akhirnya anak tidak akan merasakan kesulitan serta selalu bersemangat ketika melakukankegiatan. Selain gerakan, lagu yang digunakan oleh peneliti mer upakan lagu yang telah disesuaikan

${ }^{9}$ Ni Kadek Nelly Paspiani, 'Kegiatan Latihan Gerak Dan Lagu (Jeruk Bali) Untuk Meningkatkan Perkembangan Motorik Kasar Pada Anak Usia Dini', Pendidikan Anak, IV.1 (2015), 538-543.

${ }^{10}$ Pertiwi. A. H. D., 'Pengaruh Pembelajaran Gerak Dan Lagu Terhadap Kecerdasan Kinestetik Anak Usia Dini’, 2014. 43-50 
dengan karakter anak.Nada untuk anak seusia paud tidak melibihi dari1 oktaf, bahasa yang digunakan pun bahasa yang sesuai untuk anak sehingga mudah diingat.

Oleh karna itu optimalisasi metode gerak serta lagu anak usia paud sangatlah penting.Dan dalam mengembangkan sumber daya anak yang cerdas sangat strategis ketika berada pada anak-anak.

\section{KECERDASAN ANAK}

Kecerdasan, menurut Howard Gardner (dalam Muhammad Alwi) merupakan kemampuan untuk menangkap situasi baru serta kemampuan untuk belajar dari pengalaman masa lalu seseorang. Selanjutnya Horward Garner mengatakan bahwa era baru sudah mengubah dari IQ yang hanya tes tulis (yang diominasi oleh kemampuan matematika dan bahasa) menjadi Mutiple Intelligences.Pengetahuan bisa menyelesaikan persoalan yang dialami pada kehidupan nyata, juga dapat menciptakan persoalan-persoalan lebih lanjut berdasarkan persolan yang dipecahkan, untuk mengembangkan pengetahuan yang amat maju serta canggih.

Kecerdasan gerak-kinestetik berkaitan dengan kemampuanmenggunakan gerak seluruh tubuh untuk mengekspresikan ide danperasaannya serta keterampilan menggunakan tangan untuk menciptaatau mengubah sesuatu. ${ }^{11}$ Kecerdasan ini termasuk kecerdasan merangsang akan peristiwa-peristiwa baru untuk ditanggapi.

Kecerdasan anak juga dapat dilihat bakatnya secara fisik bagaimana ia bisa terampil memainkan tangannya. Kecerdasan yang setara dengan kecerdasan lainnya.Kecerdasan Musikal adalah kemampuan mempersiapkan, membedakan dan mengekspresikan bentuk-bentuk musik.Kecerdasan ini melibatkan kepekaan ritme, melodi, dan bunyi musik lainnya dari sesuatu ciptaan musik.Termasuk dalam kecerdasan ini adalah memiliki kemampuan pemahaman musik, baik pemahaman dari atas kebawah atau sebaliknya ataupun kedua-duanya (global ataupun intuitip, ataupun dalam analitik dan teknikal). ${ }^{12}$ Akan tetapi, sebelum anak dapat mengekspresikan

${ }^{11} \mathrm{~N}$ Widianawati Inovete.(2), 'Pengaruh Pembelajaran Gerak Dan Lagu Dalam Meningkatkan Kecerdasan Musikal Dan Kecerdasan Kinestetika Anak Usia Dini', Academia.Edu, 2.Edisi Khusus (2011), 220-228 <http://www.academia.edu/download/34063262/22NANA_WIDHIANAWATI-bl.pdf>.

${ }^{12}$ A.A Istri Intan Ari Lastari, I Ketut Gading, and Putu Aditya Antara, 'Penerapan Pembelajaran Gerak Dan Lagu Berbantuan Audiovisual Untuk Meningkatkan Kecerdasan Kinestetik Pada Anak Kelompok B', E-Journal Pendidikan Anak Usia Dini, 4.2 (2016). 45-47 
gerakannya, hendaknya sudah dapat mengetahui variasi gerakan-gerakan tubuhnya.Anak yang memiliki kecerdasan kinestetik yang baik dengan sendirinya juga akan memiliki kekuatan (strength) yang relatif lebih baik dibandingkan dengan mereka yang kecerdasan kinestetiknya kurang. ${ }^{13}$

\section{OPTIMALILASI METODE GERAK SERTA LAGU UNTUK MENINGKATKAN KECERDASAN}

Mutu pendidikan akan meningkat jika diiringi dengan perubahan dan perkembangan dalam pendidikan. Diantara cara meningkatkan kualitas pendidikan secara keseluruhan adalah dengan ditingkatkannya kualitas pembelajaran yang salah satunya adalah optimalisasi program atau peningkatan program cara mengajar. Dikatan relevan jika metode mengajar dapat mengantarkan anak dalam meraih tujuan pendidikan terhadap pembelajaran.

Karena pembelajaran ini dianggap penting, maka diperlukan untuk mempersiapkan kondisi-kondisi yang dapat memberikan kemungkinan terhadap anak didik supaya bisa menyalurkan bakat serta kreativitasnya secara optimal.

Keberhasilan pendidikan bisa terlihat dari keberhasilan suatu pembelajaran. Sebuah pembelajaran amat ditentukan oleh kemampuan seorang guru ketika mengajari anak didiknya, ${ }^{14}$ sebab pada proses belajar yang bertatapan langsung dengan anak didik adalah guru. Banyak hal yang bisa ditempuh agar dapat mencapai tujuan tersebut. Dari itu gurusebaiknya membuat program yang bisa membuat anak bertambah cerdas. Pembelajaran yang kreatif merupakan pembelajaran denga menggunakan metode unik yang dapat merangsang pola pikir anak dalam perkembangan melalui kegiatan bernyanyi serta bergerak diikuti irama musik.

Juga, guru harus bisa membuat suasana belajar yang menyenangkan dan dapat membuat siswa lebih berminat serta termotivasi untuk belajar sehingga aktivitas anak didik dalam belajar meningkat. Karena itu diperlukan suatu cara mengemas

\footnotetext{
${ }^{13}$ Eny Kusumastuti Elisabeth Tri Kurnianti Sudjono, 'Proses Pembelajaran Gerak Dan Lagu Yang Kreatif Berdasarkan Kurikulum 2013 Di Tk Miryam Semarang', Jurnal Seni Tari, 6.2 (2017), 9.

14 Yuli Andriana. Hasan Baharun, Vidyatul Muyassaroh, Model Dan Desain Pembelajaran Inovatif, Kreatif Dan Berkarakter (Probolinggo: Pustaka Nurja bekerjasama dengan Duta Media, 2018).
} 


\section{Rifatin}

pembelajaran yang inovatif dalammenyampaikan pembelajaran pembelajaran kepada anak didik. Salah satunya adalah dengan bernyanyi.Dengan mengemas materi-materi pembelajaran dalam bentuk nyanyian, diharapkan siswa mudah menerima materi dan merasa senang bermain bersama teman-temannya. Pendekatan belajar dengan bernyanyi sebagai metode pembelajaran, tentulah sangat efektif, karna anak-anak suka bernyanyi.Namun nyanyian-nyanyian edukatif yang menunjang sebuah pembelajaran, ternyata jumlahnya masih terbatas. Oleh hal itu, perlunya mengubah nyanyian populer anak digabungkan untuk dengan materi pembelajaran, nyanyian-nyanyian hasil gubahan itu bisa membantu anak-anak dalam materi pembelajaran. ${ }^{15}$ Motivasi yang diberikan kepada anak karena hirarki motivasi dilihat pada kebutuhan manusia yaitu kebutuhan terhadap harga diri serta kebutuhan aktualisasi diri, sehingga motivasi atau dorongan yang diperoleh, dapat mendorong siswa untuk memperoleh hasil belajar yang maksimal.

Pada usia anak-anak maka kemampuan dalam menyerap materi gerak juga masih bersifat main-main belum bisa berlatih secara serius, melaluigerakan-gerakan yang diberikan. Sehingga tidakakan merasa kesulitan serta selalu bersemangat ketika melakukan kegiatan.Selain gerakan, lagu yang digunakan oleh peneliti mer upakan lagu yang telah disesuaikan dengan karakter anak.Nada untuk anak-anak tidak melibihi dari1 oktaf, bahasa yang digunakan pun bahasa yang sesuai untuk anak sehingga mudah diingat. ${ }^{16}$ pada usia anak-anak dini anak masuk dalam kelompok usia bermain, maka kemampuan dalan menyerap materi gerak juga masih bersifat mainmain belum bisa berlatih secara serius.

Untuk mengatasi hal tersebut, sebaiknya guru berusaha menerapkan sebuah strateg-strategi baru yaitu menggunakan metode bernyanyi guna memudahkancara belajar anak didik.Dengan bernyanyi diharapkan anak didik dapat belajar dengan suasana yang riang dan gembira.Penerapan metode bernyanyi didalam pembelajaran, teori ini sangat gampang dan mudah dilakukan. Namun seiring kemajuan zaman teori ini juga semakin berkembang, metode lagu dalam pembelajaran terbagi menjadi dua fase yaitu: Pertama bernyanyi menggunakan media, dimana guruharus

\footnotetext{
${ }^{15}$ Psikologi Bermain and Anak Usia Dini, 'Pr'. 2015, 6-7

${ }^{16}$ Imam Suhaimi and Universitas Kahuripan Kediri, 'Memberdayakan Kecerdasan Kinestetik Anak'. 2017, 73-74
} 
mempersiapkan sebuah materi yang sudah dimasukkan dalam media, contohnya lagu berbentuk video. Dengan menampilkannya di depan siswa danmenginstruksikan untuk bernyanyi bersama dan ini bisa dilakukan dengan video atau MP3. ${ }^{17}$ Kedua bernyanyi tanpa media, ini merupakan cara lama bagi seorang guru yang memiliki kemampuan dalam tarik suara. Hal ini sangatlah pantas untuk dilakukan untuk mempersiapkan materi untuk dinyanyikan didepan siswa.

Masa anak-anak, otak reptile dan otak mamalianya telah berkembang sekitar 80\%. Pada saat irtulah berbagai kecerdasan anak terbuka.Kecerdasan kinestetik adalah suatu kecerdasan dimana saatmenggunakannya kita mampu melakukan gerakan-gerakan yang bagus berlari, menari, membangun sesuatu, semua seni serta hasta karya. Banyak orang berbakat secara fisik serta"terampil menggunakan tangan" tidak menyadari bahwa mereka menujukkan bentuk kecerdasan yang tinggi. ${ }^{18}$ Masa kecil adalah masa yang amat ideal untuk mempelajari atau melatih kecerdasan kinestetik anak.Rangsangan terhadap kecerdasan gerak kinestetik dapat meningkatkan pertumbuhan anak, sesuai karakter anak yang aktif bergerak.

Dalam pembelajaran sebaiknya melihat kecendrungan ini. Kecerdasan kinestetik dapat di rancang dengan permainan-permainan yang memungkinkan anak bergerak dengan tumpuan otot dan keseimbangan, keluwesan dan kelenturan.Sejak dilahirkan anak sudah mempunyai kecerdasan yang berkaitan dengan Kecerdasanperkembangan otak. 50\% kecerdasan pada masa anak-anak (usia dini). Pembelajaran gerak serta lagu amat melekat erat serta tidak bisa terpisahkan terutama ketika memberikan pembelajaran kepada anak-anakusia dini. Oleh karenanya perlu adanya suatu kegiatan yang bisa melatih para pendidik anak usia dini dalam memberikan rangsangan terhadap anak memalui gerak serta lagu.

Langkah-langkah meningkatkan program gerak dan lagu anak usia dini

1. Memperhatikan kondisi psikologis anak kemudian tema dari gerak lagu, klo itu memungkinkan untuk bernyanyi maka anak lebih baik diaja untuk bernyanyi terlebih dahulu

\footnotetext{
${ }^{17}$ Denok Dwi Anggraini, 'KEGIATAN BERMAIN SIRKUIT DENGAN BOLA ( Penelitian Tindakan Di Kelompok A TK Al Muhajirin Malang Jawa Timur, Tahun 2015 )', 2015, $65-75$.

${ }^{18}$ Penelitian Tindakan and B Kelompok, 'PEMBELAJARAN GERAK DASAR TARI MINANG Mahasiswa Pascasarjana Universitas Negeri Jakarta', 2015. 235-236.
} 
2. Memilih gerak lagu yang mempunyai tema alam sekitar atau tentang kehidupan sehari-hari.

3. Memilih gerak lagu yang mempunyai gerak yang tidak sulit untuk anak mudah meniru.

4. Memilih gerak lagu atau tari yang mempunyai gerak komikal.

5. Memilih gerak lagu atau tari yang mempunyai alur dinamik sedang, lembut dan keras/cepat, karna variasi dinamik akan melatih variasi emosi anak.

6. Membuat berbagai macam gerak dan lagu atau tari semudah mungkin dan selalu memperhatikan.

7. Memilih gerak dan lagu serta tari secaraberkelompok karna menanamkan rasa kerja sama, saling menghargai yang bisa mengarah pada kematangan social anak.

8. Sebelum mengajar pendidik harus betul-betul mengusai pembelajaran gerak, tari dan lagu.

9. Memberikan bentuk-bentuk gerakan dengan bertahap.

10. Membuat selingan-selingan dengan cerita yang relevan dari tema gerak lagu/tari yang akan diajarkan.

11. Melakukan pengulangan-pengulangan gerak.

12. Kegiatan gerak serta lagu dibagi dalam beberapa pertemuan oleh guru.

Setelah melaksanakan optimalisasi metode gerak lagu, guru harus berupaya merancang semua kegiatan tentang gerak dan lagu agar lebih meningkataan perhatian dan memberi dorongan kepada anak-anak sehingga gerakan apapun yang diarahkan oleh guru dapat diikuti oleh anak dengan baik. Disamping itu, guru akan lebih memberikan motivasi berupa penguatan, dorongan serta semangat dan juga mencari sesuatu yang menarik sehingga memunculkan semangat terhadap anak-anak didik untuk melatih keterampilan dengan baik. 


\section{KESIMPULAN}

Optimalisasi metode gerak serta lagu amat bermanfaat untuk kecerdasan anak usia dini. Terutama kecerdasan kinestetiknya.Karna gerak dan lagu merangsang perkembangan anak. Melalui gerak serta lagu diharapkan akan menjadikan anak-anak usia dini sebagai penerus bangsa yang lincah,berbakat, kreatif dan bersahaja. Guru sudah sepatutnya dapat meningkatkan kompetensi termasuk kompetensi profesional dan membekali diri dengan pengetahuan yang luas, sebab sesungguhnya kompetensi yang dimiliki oleh seorang guru amat mempengaruhi keberhasilan proses pembelajaran, yang akhirnya akan bisa menghasilkan peserta-peserta didik cerdas dan kreatif.

\section{DAFTAR PUSTAKA}

Anggraini, Denok Dwi, 'KEGIATAN BERMAIN SIRKUIT DENGAN BOLA ( Penelitian Tindakan Di Kelompok A TK Al Muhajirin Malang Jawa Timur, Tahun 2015 )', 2015, 65-75

Baharun, Hasan, Pengembangan Kurikulum : Teori Dan Praktik (Konsep, Prinsip, Model, Pendekatan Dan Langkah-Langkah Pengembangan Kurikulum P AI) (Yogyakarta: Cantrik Pustaka, 2017)

Bermain, Psikologi, and Anak Usia Dini, 'Pr'

D., Pertiwi. A. H., 'Pengaruh Pembelajaran Gerak Dan Lagu Terhadap Kecerdasan Kinestetik Anak Usia Dini', 2014

Elisabeth Tri Kurnianti Sudjono, Eny Kusumastuti, 'Proses Pembelajaran Gerak Dan Lagu Yang Kreatif Berdasarkan Kurikulum 2013 Di Tk Miryam Semarang', Jurnal Seni Tari, 6 (2017), 9

Hasan Baharun, Vidyatul Muyassaroh, Yuli Andriana., Model Dan Desain Pembelajaran Inovatif, Kreatif Dan Berkarakter (Probolinggo: Pustaka Nurja bekerjasama dengan Duta Media, 2018)

Indahsari, Dudi Gunawan \& Marisyanti, 'Pengembangan Keterampilan Gerak Dasar Motorik Kasar Melalui Pembelajaran Seni', Jurnal Penelitian Pendidikan, 16 (2016), 32-39

Inovete.(2), N Widianawati, 'Pengaruh Pembelajaran Gerak Dan Lagu Dalam Meningkatkan Kecerdasan Musikal Dan Kecerdasan Kinestetika Anak Usia Dini', Academia.Edu, 2 (2011), 220-28

Kadarwati, Sri, 'Mengembangkan Kecerdasan Anak Usia Dini Melalui Pembelajaran Berbasis Pendidikan Kreatif, 2, 43-66

Lastari, A.A Istri Intan Ari, I Ketut Gading, and Putu Aditya Antara, 'Penerapan Pembelajaran Gerak Dan Lagu Berbantuan Audiovisual Untuk Meningkatkan Kecerdasan Kinestetik Pada Anak Kelompok B', E-Journal Pendidikan Anak Usia Dini, 4 (2016)

Paspiani, Ni Kadek Nelly, 'Kegiatan Latihan Gerak Dan Lagu (Jeruk Bali) Untuk 
Rifatin

Meningkatkan Perkembangan Motorik Kasar Pada Anak Usia Dini', Pendidikan Anak, IV (2015), 538-43

Suhaimi, Imam, and Universitas Kahuripan Kediri, 'Memberdayakan Kecerdasan Kinestetik Anak'

Suryana, Dadan, 'Hakikat Anak Usia Dini', Dasar-DasarPendidikan TK, 2014, 65

Tindakan, Penelitian, and B Kelompok, 'PEMBELAJARAN GERAK DASAR

TARI MINANG Mahasiswa Pascasarjana Universitas Negeri Jakarta', 2015

Wulandari, Retno Tri, 'Pembelajaran Olah Gerak Dan Tari Sebagai Sarana Ekspresi Dan Apresiasi Seni Bagi Anak Usia Dini'

Yunita, Yenti, 'Meningkatkan Kecerdasan Kinestetik Anak Melalui Teknik Bernyanyi

Lagu-Lagu Di Tk Aisyiyah 1 Curup’, 2014 